\title{
Foreword
}

\section{Transitional justice: (re)conceptualising the field}

\author{
Christine Bell, Colm Campbell and Fionnuala Ní Aoláin \\ Transitional Justice Institute, University of Ulster ${ }^{1}$
}

Transitional justice discourse is generally accepted as having its foundations located in the theoretical, policy and practical implications of dealing with past human rights violations in societies that have experienced either repressive politics or violent conflict. Many theorists and policy-makers resolutely assume or defend the notion that 'dealing with the past' is where the debates about, and contribution of, the transitional justice paradigm uniquely lie. ${ }^{2}$ Understood in this way, transitional justice as a field of study has grown exponentially, comprising theoretical debates, the comparative assessment of domestic accountability schemes, international criminal justice, the study of truth commissions, and ethical-legal debate concerning the morality of compromise on accountability for gross and systematic violations of human rights.

This foreword, building on the previous work of its authors, ${ }^{3}$ extends and expands our contention that transitional justice in this narrow sense must be located in a broader and more problematised understanding of justice in contemporary transitions. We also use the opportunity provided by this symposium to highlight an expansion of conceptual horizons being carried out at the Transitional Justice Institute (University of Ulster), and the innovative approach to the transitional justice field being advanced by a group of diverse inter-disciplinary scholars. The approach advocates both drawing on other disciplines, and firmly supporting parallel disciplinary fields to work alongside a legal research agenda; affirming the importance of rigorous cross-jurisdictional comparisons; and utilising empirical and socio-legal methodology to advance legal inquiry.

We affirm, as we have previously asserted, that transitional justice constitutes a field of inquiry that both affirms but also problematises the role of law in situations of societal change (Bell, Campbell and Ní Aoláin, 2004). We are not concerned to enter a debate that we view as essentially semantic, namely whether the term 'transitional justice' should be used primarily to communicate a narrow or broader meaning. Rather, we wish firmly to assert our vision of a continuum which extends from a narrow (past-focused) notion of 'transitional justice' to a broader consideration of the role of law in transitions (itself a subset of the question of justice in transition). From this perspective, it is clear that the legal frame of reference is only one dimension of a broader attempt at social and political change.

This points to the underlying project on any 'law in context' exploration - to question the complexities of what it means to 'normativise' what could be seen (and indeed at the beginning of the I99os were argued to be) questions for the realm of politics. We have suggested elsewhere that 'transitional justice' does not have an even meaning across contexts, as illustrated by the

I We note our thanks to Catherine O'Rourke, Transitional Justice Institute, for research assistance in completing this foreword and to Dr Shane Darcy for his oversight in bringing the work of this symposium to fruition.

2 See e.g. Bickford (2004): "Transitional Justice refers to a field of activity and inquiry focused on how societies address legacies of past human rights abuses, mass atrocity, or other forms of severe social trauma, including genocide or civil war, in order to build a more democratic, just or peaceful future.'

3 This foreword also gives us a substantial opportunity to respond to critical probing of our analytical approach. See e.g. Hannum (2006). 
appropriation of the language of 'transitional justice' in pursuit of hegemonic legitimation in Iraq (Bell, Campbell and Ní Aoláin, 2007) (a point explored further below). ${ }^{4}$ Such minefields caution vigilance but not timidity as we proceed.

\section{Transitional justice as dealing with the past}

We acknowledge that the field's roots lie squarely in controversies over accountability, where in Koskenniemi's (2002) terms the ' $\ldots$. universalisation of the Rule of Law [called] for the realization of criminal responsibility in the international as in the domestic sphere'. Transitional justice as the study of mechanisms focused on past abuses can be traced to the post-Second World War Nuremberg and Tokyo tribunals. In the I980s and I990s the field was reinvigorated and invested with new meaning as a response to the systematic human rights violations carried out by repressive Latin American states, the transitions in Eastern Europe, and peace negotiations in an ever-expanding list of 'intra-state' conflicts. Two trends can be identified in this latter period. The first was a rise in innovative Truth Commission-type mechanisms as a way of squaring accountability v. amnesty debates, that were characterised by being rooted in broad range of justice and social goals other than individual criminal accountability. These goals were implemented by de-legalised processes justified both in terms of pragmatic and principled arguments as more suitable to the outcomes sought. ${ }^{5}$ The second (apparently antithetical) trend was the rise in international criminal justice, evident in the establishment of the Yugoslav and Rwanda Tribunals and the Ad hoc Tribunal for Sierra Leone, and the institutionalisation of such initiatives in the creation of an International Criminal Court. ${ }^{6}$

The broader project of considering 'justice in transition' responds directly to the past-focused conception of transitional justice. We assert, first, that mechanisms for dealing with the past cannot be considered without locating them in the broader question of the connection between mechanisms for the past and the broader constitutional frameworks that the methods are in service to. Viewed from the wider perspective of 'constitutional meta-bargaining,', the role of law in dealing with the past appears contingent. This approach questions any idealisation of the end game of a narrowly delineated 'transitional justice' discourse, defined purely in terms of criminal accountability, lustration or state-building (including definitions resting upon such underlying theories as liberalisation or deterrence). ${ }^{8}$

Related to this is our second assertion that 'past-focused' mechanisms are in practice negotiated as merely one part of a transformation package. Meaningful societal change (of which accountability is likely to be a key part) requires the overhaul of political, legal and social institutions. Political trade-offs frequently occur across a variety of issues, with the result that the factors affecting which mechanism is put in place cannot be fully understood without appreciating their place in the overall package.

4 See also Bell and O'Rourke (2007), arguing in conclusion that the justice meaning of transitional justice varies from context to context.

5 For an exploration of the gender specific limitations of transitional accountability mechanisms, see Ní Aoláin and Turner (2007).

6 For a detailed overview of this genealogy, see Teitel (2003).

7 On meta-constitutionalism, see Walker (2002).

8 Koskenniemi (2002) has, inter alia, identified that: ' $\ldots$.. studies on the transformations of authoritarian regimes into more or less liberal democracies... have suggested a more complex understanding of the role of criminal trials as not merely about punishment or retribution, not indeed about deterrence, but as aspects of a larger "transitional justice".' 


\section{From transitional justice to rule of law}

To some extent, recent developments relating to 'transitional justice' in its narrower sense have begun to affirm these types of connections. Most notably, in a policy context, the United Nations Secretary-General has recognised an organic relationship between 'transitional justice' and the rule of law (United Nations Secretary-General, 2004). This recognition has vital policy implications, signalling both the broad institutional appropriation of the term 'transitional justice', as well as the fact that it is fast becoming a by-word for a bundle of transformative efforts, mostly of a legal nature. That recognition has ignited a broader international policy conversation to which, we suggest, this theoretical re-mapping has an important contribution to make. ${ }^{9}$

While focus on the rule of law locates 'transitional justice' within a broader framework, it also prompts the question of 'which concept of the rule of law?' - and in particular whether a formal (procedural) or substantive (value-based) emphasis is to be preferred. If the former, then the programme of reform seems to be a technical bureaucratic one in which international organisations can play a seemingly uncontroversial role by assisting in rolling out reform of constitutionalised legal institutions: an independent judiciary, separation of powers, an impartial and accountable police force? However, if a more substantive articulation is preferred - or understood to be implicated in formal understandings of the rule of law - then the crucial question is: what values or whose values does it presuppose? ${ }^{\text {IO }}$

Whether the 'rule of law' is to be understood in procedural or substantive terms, is essentially a philosophy of law debate. This very debate risks diverting attention from a key insight of the law and society movement: the well-documented capacity for law (even, or perhaps especially, in societies with an ideological commitment to the 'rule of law') to be an instrument of gender, ethnic, economic and class oppression. Moreover, transitions add new practical and conceptual complexity to longstanding rule of law debates. Transitions are typically situations in which the very concept of the rule of law appears to require rehabilitation precisely because it has operated as the chassis to which the vehicle of systemic human rights violations has been harnessed. The paradox arises because law as a tool of reform must itself be radicalised to function appropriately in the new dispensation.

Domestic law's hegemonic quality - its tendency to buttress powerful societal forces, make it an unreliable check on oppressive power even in settled societies, yet its 'relative autonomy' and its associated counter-hegemonic potential mean that it cannot entirely be dismissed as a vehicle for progressive societal change. The question of law's capacity to deliver (or hinder) meaningful change in transitional societies is an open one, and must be considered part of a broad 'transitional justice' research agenda. At the very least, there needs to be an awareness that legalism, a focus on law's normativity, and the imperative to frame questions in legal terms, may privilege elite understandings, and render invisible key issues affecting disenfranchised groups (Campbell, Ní Aoláin and Harvey, 2003). A broader understanding of law's operation in societal transitions is likely to require an investigation of the deployment of law by disenfranchised social movements, an investigation that will need to involve disciplines other than law, and one that is likely to focus at least on much on law as a system of communication and on its instrumentality, as on its normativity. It is also likely to require cross-jurisdictional comparisons, not least because such comparisons offer a route to separating the specificity of the local from recurring patterns in relation to the deployment of law.

9 See also Kritz (I996), who argues that: 'The rule of law does not simply provide yet one more vehicle by which government can wield and abuse its awesome power; to the contrary, it establishes principles that constrain the power of government, oblige it to conduct itself according to a series of prescribed and publicly known rules.' But cf. Paris (2004).

Io For a useful summary of different approaches to the rule of law that also illustrates some inevitable linkage between formal and substantive conceptions, see Craig (I997); see also Carothers (I998). 
Transitional justice 'from below' demands exploration with at least as much urgency as that 'from above'.

Secondly, with their unique international/domestic 'hybridity' (Bell, 2006), transitions pose a particular 'law in context' question around what the context for understanding rule of law valueformation is, and in particular whether the frame of reference is an international one in which values are understood with reference to international standards, a domestic one located in domestic constitutional understandings, or one in which the meaning is constructed dialogically through on-going negotiation (either within the domestic sphere, or in a broader negotiation across both spheres).

In the contemporary uni-multipolar world, this begs the question adverted to earlier, of the relationship between the world's sole remaining superpower, international law, and transitional justice, with Iraq as the prime site of inquiry. In many respects the international law debate mirrors that in domestic law: international law is likely to accommodate itself to the exercise of hegemonic power (Campbell, 2005), and offers powerful legitimating potential, but some possibility for lawbased challenge is likely to be present (Krisch, 2005), and international law is always likely to retain some 'pull', even on powerful states (Byers, 2003). This pull may be particularly strong in transitional societies where a context of conflict can no longer be invoked to justify departure from international standards. Equally, the intimate oversight relationship between international institutions and such societies creates powerful incentives for such state to 'play ball' (or be seen to) with international legal norms.

In Iraq, the US has used past-focused transitional justice discourse to justify and underwrite the 'de-Ba'athicisation' processes, attempting at a subtle level to justify its own role as 'democratiser' rather than 'occupier'. 'The' conflict (or the undemocratic era for which accountability is required) is thereby defined as the one that preceded and was 'ended' by its use of force (Bell, Campbell and Ní Aoláin, 2007). Prisoner ill-treatment in Abu-Ghraib, and other alleged abuses in Iraq fall outside this frame; to that extent, there is an attempt to employ 'transitional justice' both as a framing narrative that doubles as an instrument of hegemonic power. Whether the US will succeed or not in this attempt is an open question, one given particular salience by identifying Iraq as merely one site in a never-ending (and to that extent 'ordinary') 'war on terror'. The complexity here is evident from the inter-connectedness of transitional justice with multiple and overlapping spheres of international law, as well as from its becoming knitted into the unsettled sphere of local law (which itself is reconfigured by external legal interface to 'fit' the transitional narrative being advanced). ${ }^{\mathrm{II}}$ Recognition of the ambivalent role of domestic law in societal transitions must thus be an accompanied by a appreciation of the ambivalent position occupied by transitional justice in the contemporary world, particularly where it is yoked to the instrumental goals of the 'war on terror' (Teitel, 2003).

\section{The symposium}

This symposium reflects some of the constitutive elements of this broadening and revisioning. It also reflects unique methodological strengths. These strengths include a broad inter-disciplinary approach to the analysis of transitional problems, a socio-legal dimension to conduct of legal inquiry, an affirmation of the value of doctrinal analysis in the transitional setting, an emphasis on mid-level theorising about legal institutions, norms and 'messaging', in order to probe their transformative capacity.

I I On global-local interface in transition, see Campbell and Fionnuala (2003). 
So, for example, 'dealing with past' remains a core aspect of the transitional justice inquiry, but is given fresh vitality in the symposium. The contribution made by Kirk Simpson entitled Voices Silenced, Voices Rediscovered confirms the centrality of the past to the construction of legal and political futures, with its emphasis on the need to reclaim the 'pre-language' state which frequently obscures the ability of victims to contribute effectively to truth processes. Precisely because the analysis locates law within an anthropological understanding, it demonstrates the manner in which existing literature on voice and victims can be re-interpreted and reinvigorated by understanding law's limits as a language.

Venkat Iyer's contribution to this symposium is concerned with the importance of constitutional structures and norms in the transitional phase. This emphasis on norm content, its institutional outworkings and constitutional configurations augment the contention we make that transitional justice is fundamentally concerned with the operation and rehabilitation of law in post conflict and repressive societies. Iyer's assessment demonstrates the importance of the local/global interchange for enriching the transitional justice field.

Complementing this approach is the contribution by McKeever and O’Rawe, who highlight the significance of institutional legal reform through a succinct assessment of the relationship between citizenship, policing and the role of ex-combatants in post-conflict societies. The essential quandary they address is framed by exploring the question of whether paramilitary ex-prisoners should be allowed to join the police force. The article affirms the broader linkage between transitional justice narrowly defined, with rule of law issues generally defined, as well as the concrete contribution that institutional change has for the success of the transitional project - particularly to those who have been excluded or marginalised in the prior dispensation.

Finally, the work of Rooney and Reilly brings gender to the forefront of transitional justice explorations. Both contributions are grounded in the broad inter-disciplinary methods advocated in this foreword, and both attest to the strength of analysis that emerges when the role of law is interposed alongside rigorous feminist method. Rooney's contribution tackles a key legal site of transitional justice - namely the peace agreement - and undertakes an ambitious interweaving of intersectionality theory with the presence or absence of women in such sites. The analysis again confirms the pivotal influence that legal frames have on outcomes, and the organic link between institutional decision-making sites with transformative outcomes. Reilly undertakes a critical consideration of dominant approaches to transitional justice, and probes what is necessary to achieve 'justice' for women in transitional context. Her extensive survey of international accountability mechanisms is notably informed by considering the merits of a 'bottom up' rather than 'top down' approach to gender accountability, and places significant emphasis on comparative knowledge as to the influence of transnational influences on processes which affect women.

\section{Transition, justice and law}

What then are the elements that need to be developed in the broader conception of the field?

\section{(a) Understanding transition}

Transitions have been at the margins of traditional legal categories. Similar, for example, to legal doctrines of exceptionality, transitions often stood at the sidelines of legal and theoretical scholarship. ${ }^{\text {I2 }}$ This is no longer the case. The number and scale of societies experiencing transition from repression and/or conflict allied to the broader geo-political effects of instability and inter-dependence caused by it, and the growth of the international tribunal model, have meant that transitional justice

I2 See Oren and Ní Aoláin (2006) for a detailed overview of the exception and its marginal place in legal scholarship historically. 
has become an overarching legal and political mantle to accommodate, manage and prompt such change. One contemporary feature of the discourse is the blurring of definitional boundaries about what is 'in' and 'out' of the transitionary paradigm. This can be viewed either as a denial of the specificity of transitions from conflict (Posner and Vermeule, 2004), or as an attempt to unsettle established constitutional orders so as to radicalise and re-envision processes of democratic renewal. ${ }^{13}$ From this point of view, arguments about what constitutes 'the field' become difficult to separate from strategic instrumentalism regarding what that the assertion of 'transitional justice' as the frame of inquiry aims to achieve. ${ }^{\mathrm{I}}$ But ambivalences identified above in the problematic contemporary employment of transitional justice discourse also manifest under this heading. Current 'steady state' transitional justice (evident in the creation of the International Criminal Court) may operate to universalise the exception. The concept may therefore be open to appropriation in an attempt to re-work mainstream understandings of international legal norms. What was viewed as a legal phenomenon associated with extraordinary post-conflict conditions now increasingly appears to be a reflection of ordinary times. This poses extra-ordinary challenges to the integrity of the field.

\section{(b) Understanding of justice}

It becomes evident that, in addition to the reframing we have outlined above, the conception of transitional justice implies that some understanding and even theory of 'justice' is either implicit or required. In this vein of analysis 'justice' often stands as a short-cut for 'law' or 'legal'. Such an analysis is extremely loose analytically but has the advantage of providing a very large canvas - it is not limited to dealing with the past. Transitional justice on this understanding could broadly cover the role of law in situations of transition. Despite its ease we do not use this analytical shortcut. In our view, it holds two distinct disadvantages: first, it makes Transitional Justice essentially a game for lawyers. It eschews a broader inter-disciplinary capacity and ensures that political scientists, sociologists, anthropologists and others are marginalised. ${ }^{15}$ Second, it glosses over some complex and relevant jurisprudential debates concerning the content of 'justice', and it gives no sense of the continuum of interface which we prompt reflection on in this foreword.

A second approach is to view justice in the context of theories of justice. This is arguably where legal theory is now turning. It is unnecessary at this point to probe the array of justice theories on offer; suffice to say that there are a great variety of theoretical explorations of the concept of justice, many of which can usefully be explored in relation to the specifics of 'transition'. Taking this approach has a number of advantages. Primarily, it opens the field to the broad and deep interdisciplinary engagement that we suggest is critical to any expansive understanding of transitional justice. Importantly, transitional justice is then no longer narrowly confined to a lawyers' discourse. Second, it takes the theoretical debates from the transitional context and forces their engagement with mainstream 'justice' scholarship. It also has a number of disadvantages. First, it tends to encourage a narrow competitive trade-off between differing theories of justice (my theory is 'better', or at least 'bigger' than yours), potentially focusing on philosophy of law quandaries to the neglect of socio-legal insights. Second, the emphasis on theory choice and fit tends to assume or defend, rather than interrogate the goals of transition.

The way forward that we are traversing, as illustrated by this symposium, is one that first of all disaggregates the different points at which law 'connects' with transition adopting what can loosely

I3 See Bell and O’Rourke (2007, pp. 42-4). Cf. Tully (I995).

I4 Cf. Berman (2004); cf. also Bell, Campbell and Ní Aoláin (2007).

I5 See Campbell, Gross and Ní Aoláin (2007) arguing for a deep inter-disciplinary approach to contemporary conflict-related legal problems; see also Campbell and Connolly (2006). 
be called a 'law in context' approach to each one, that eschews any understanding of law as purely normative, or indeed as indistinguishable from politics. ${ }^{16} \mathrm{We}$ have laid these points of connection as follows:

- Understanding the role of law in conflict.

- Law and Political institutions (constitutionalism).

- Law and Legal institutions ('rule of law').

- Dealing with the past ('transitional justice').

- Gender issues (cross-cutting and also a discrete field of inquiry, and capable of expansion into a broader conception of all the 'others' seen as marginal to the violent conflict).

- Law and social movements (transitional justice 'from below').

Second, we attempt to understand the role of law in transitions by using (sometimes on their own, often together), a range of methodologies, so as to understand how law is conceived to apply or not apply in a positive sense, but to assist with understanding the role of law in context. These methodologies primarily include:

- Legal doctrinal (focused around the lack of 'fit' between transition and traditional international legal doctrine).

- Socio-legal and more broadly interdisciplinary (aiming to understand the role and limits of law within a contextualised understanding of its relationship to politics and other social processes); we affirm that this may involve analysis of both qualitative and quantitative empirical data.

- Theoretical (theorising transition and justice, and their inclusions and exclusions).

To put it boldly, we view study of 'transition and justice' as providing an important contribution to some of the deepest quandaries of law's relationship to social change, well beyond the transitional context.

\section{Conclusion: (re)conceptualising the field}

In conclusion, we are pleased that this Special Issue of the Journal of Law in Context has afforded the opportunity for a selection of the diverse and inter-disciplinary research agenda of the Transitional Justice Institute to be drawn together and presented here. The range of scholarly interests, and the rare mix of legal and other disciplinary approaches to core transitional issues, illustrate precisely the themes that this foreword has sought to highlight; namely that the field of transitional justice has widened and deepened - that it is not the domain of lawyers alone - and that it is no longer solely probing accountability concerns. Rather, the field is now firmly engaged in a wider set of inquiries about the role of law in the process of societal change - and the interface and consequences that follow for what we understand law to be.

\section{References}

Bell, Christine (2006) 'Peace Agreements: Their Nature and Legal Status', American Journal of International Law I00: 373-4I 2.

Bell, Christine, CAmpbell Colm and ní aoláin, Fionnuala (2007) 'The Battle for Transitional Justice: Hegemony, Iraq and International Law', in John Morison et al. (eds.), Human Rights, Democracy and Transition: Essays in Honour of Stephen Livingstone. Oxford: Oxford University Press.

I6 We note that these strengths are more widely reflected in the overall research outputs by a variety of scholars at the Transitional Justice Institute see http://www.transitionaljustice.ulster.ac.uk. 
Bell, Christine, CAMPBell Colm and Ní AOLÁin, Fionnuala (2004) 'Justice Discourses in Transition', Social and Legal Studies I3: 325-28.

BeLL, Christine and o'Rourke, Catherine (2007) 'Does Feminism Need a Theory of Transitional Justice? An Introductory Essay', International Journal of Transitional Justice I: 23-44.

Berman, Neil (2004) 'Privileging Combat? Contemporary Conflict and the Legal Construction of War', Columbia Journal of International Law 43: I-7 I.

BICKFORD, Louis (2004) 'Transitional Justice', Encyclopedia of Genocide and Crimes Against Humanity 3: I045-7.

Campbell, Colm, ní aoláin, Fionnuala and harvey, Colin (2003), 'The Frontiers of Legal Analysis:

Re-Framing the transition in Northern Ireland', Modern Law Review 66: 317-45.

CAMPBELL, Colm (2005) ' "Wars on Terror" and Vicarious Hegemons: the UK, International Law and the

Northern Ireland Conflict', International and Comparative Law Quarterly 54: 32 I-55.

CAMPBell, Colm and connolly, Ita (2006) 'Making War on Terror? Global Lessons from Northern Ireland', Modern Law Review 69: 935-57.

CAmpbell, Colm, Gross, Oren and ní aOLÁrn, Fionnuala (2007) 'The Value of the Comparative and the

International in Reflecting on State Reponses to the War on Terror', Minnesota Journal of International Law (forthcoming).

CAMpBelL, Colm and Ni Aoláin, Fionnuala (2003) 'Local Meets Global - Transitional Justice in Northern

Ireland', Fordham International Law Journal 24: I 20I-23.

CAROTHERS, Thomas (I998) 'The Rule of Law Revival', Foreign Affairs 77: 95-Io6.

CRAIG, Paul (1997) 'Formal and Substantive Conceptions of the Rule of Law: An Analytical

Framework', Public Law 33: 467-87.

Gross, Oren and ní aoláin, Fionnuala (2006) Law in Times of Crisis Emergency Powers in Theory and

Practice. Cambridge: Cambridge University Press.

Hannum, Hurst (2006) 'Human Rights in Conflict Resolution: The Role of the Office of the High

Commissioner for Human Rights in UN Peacemaking and Peacebuilding', Human Rights

Quarterly 28: I-85.

Koskenniemi, Martti (2002) 'Between Impunity and Show Trials,' Max Planck Yearbook of United Nations

Law 6: I-35.

KRISCH, Nico (2005) 'International Law in Times of Hegemony: Unequal Power and the Shaping of the

International Legal Order', European Journal of International Law I 6: 369.

KRITZ, Neil (ed.) (I996) Transitional Justice: How Emerging Democracies Reckon with Former Regimes.

Washington, DC: United States Institute of Peace, p. 588.

NI AOLÁin, Fionnuala and CAmpBell, Colm (2005) ‘The Paradox of Democratic Transitions', Human Rights

Quarterly 27: 172-213.

ní AOLÁin, Fionnuala and turner, Catherine (2007) ‘Gender Truth and Transition’ UCLA Women's Law

Review I6: (forthcoming).

PARIS, Roland (2004) At War's End: Building Peace After Civil Conflict. Cambridge: Cambridge University Press.

pOSNer, Eric and vermeule, Adrienne (2004) 'Transitional Justice as Ordinary Justice', Harvard Law

Review I I 7: 777-825.

ROBERTS, Adam (2006) 'Transformative Military Occupation: Applying the Law of War and Human

Rights', American Journal of International Law I00: 580-622.

TeItel, Ruti (2003) ‘Transitional Justice Genealogy', Harvard Human Rights Journal r 6: 69-94.

Tully, James (1995) Strange Multiplicity: Constitutionalism in an Age of Diversity. Cambridge: Cambridge

University Press.

United Nations Secretary General (2004) Report of the Secretary-General on the Rule of Law and

Transitional Justice in Conflict and Post-Conflict Societies, UN Doc. S/2004/6I6 (2004).

WALKer, Neil (2002) 'The Idea of Constitutional Pluralism', Modern Law Review 65: 317-59. 